\title{
Effect of Cooling Delays on Quality Attribute of Globe Artichoke During Cold Storage.
}

\author{
Salah E. A. Mohamedien, Mohsen EL-M. Saad; S.A. Atala and E. H.E. Afifi \\ Horticulture Research Institute, Agricultural Research Center, Giza, Egypt. \\ * Corresponding author: mohsenyoukasha@yahoo.com
}

\begin{abstract}
Artichoke heads of the cultivar "French Hyrious" were harvested at the suitable maturity stage of marketing with a dimension of $(7-12 \mathrm{~cm})$ on $14^{\text {th }}$ and $16^{\text {th }}$ of February in 2017 and 2018 seasons, respectively from Borg El-arab farm, Behera Governorate and shifted to the laboratory of Vegetable Handling Research Department, Horticultural Research Institute, Agricultural Research Center. To study the effect of cooling delay treatments for 2, 4 and $6 \mathrm{hr}$. from harvest compared with uncooled treatment (control) on quality attributes of artichoke heads during storage at $0^{\circ} \mathrm{C}$. Results showed that all cooling delay treatments reduced weight loss percentage and maintained head compactness as compared with uncooled during storage. Cooling delay for $2 \mathrm{hr}$. after harvest was the most effective treatment for maintaining quality and storability of head, which gave the lowest value of weight loss \%, maintained ascorbic acid content and TSS \%, delay color change and gave heads with good appearance for 28 days of storage at $0^{\circ} \mathrm{C}$. However, the allowable maximum for cooling delay between harvest and the start of initial cooling for artichoke heads was $4 \mathrm{hr}$., which generally did not affect the postharvest quality and gave good appearance after 28 days of storage at $0^{\circ} \mathrm{C}$. Non cooled treatment rated poor appearance at the end of storage $\left(28\right.$ days at $\left.0^{\circ} \mathrm{C}\right)$.
\end{abstract}

Key words: Globe artichoke heads, Cooling delays, cold storage, Artichoke quality.

\section{Introduction}

Globe artichoke (Cynara scolymus L.) is considered as one of the important vegetable crops for local consumption and export in Egypt. The nutraceutical properties of artichokes are mainly due to its high polyphenolic content (Azzini et al., 2007), which can be up to $2 \%$ of the fresh weight (Mileo et $a l ., 2012$ ), and the presence of fructan inulin that has been reported to have a prebiotic function that stimulates the growth of intestinal bifidobacteria (Salazar et al., 2015 and Lavermicocca et al., 2016).

However, artichoke is a highly perishable commodity, characterized by rapid rates of respiration and water loss (Kader, 1992). The main factors of artichoke heads quality degradation during prolonged storage are mostly due to decay development shriveling, associated with rapid water loss, poor external appearance, as well as reduced sensory quality.

Furthermore, at harvest, the temperature of horticulture crop is usually higher than the recommended storage range; thus artichoke heads must be precooled as fast as possible to remove field heat; preferably to $4-5^{\circ} \mathrm{C}$ (Brecht, 2008).

Postharvest cooling rabidly removes field heat, reduces postharvest decay, control development of physiological disorders, improve fruit quality and delay aging or ripening (Shehata and Tariq, 2007).

Decreasing weight loss, retention of firmness, decreasing disease incidence, retain fruit quality during storage and extend the shelf life (Becker and Fricke, 2002). Although a cooling delay sometimes occurs in the process from harvest to precooling, little is known about the effect of cooling delay on the fruit quality change. Cantwell and Thangaiah (2012) found that delays to cool reduced visual appearance quality, glossiness and firmness and enhanced water loss and increased visible symptoms of dehydration for bell peppers and eggplants. Also, concluded that for bell peppers, delays to cool should be less than $9 \mathrm{hr}$. at $20-25^{\circ} \mathrm{C}$ and less than $6 \mathrm{hr}$. at $37^{\circ} \mathrm{C}$. For eggplants, delays to cool should be less than $6 \mathrm{hr}$. at $20-25^{\circ} \mathrm{C}$ and less than $3 \mathrm{hr}$. at $37^{\circ} \mathrm{C}$. $\mathrm{Gad}$ El-Rab (2018) found that the allowable maximum for cooling delay after harvest of snap bean pods was 4 hr., which generally did not affect the quality of pods and gave pods with good appearance for 12 days of storage at $5^{\circ} \mathrm{C}+2$ days at $10^{\circ} \mathrm{C}$ (shelf life) under the experimental conditions.

Therefore, the present investigation was conducted to determine the effect of cooling delays on quality attributes of artichoke head during storage.

\section{Materials and methods}

Artichoke marketable heads of the cultivar "French Hyrious" were harvested at the suitable maturity stage of marketing with a dimension of (7$12 \mathrm{~cm}$ ) on $14^{\text {th }}$ and $16^{\text {th }}$ of February in 2017 and 2018 season respectively from Borg El-arab farm, Behera Governorate and shifted to the laboratory of Vegetable Handling Research Department, Horticultural Research Institute, Agricultural Research Center, Ministry of Agriculture, A.R.E. Heads were cleaned with dry towels, graded and free from blemishes were selected for storage experiment:

Artichoke heads were hydro-cooled after 2, 4 and 6 hours from harvest. Hydro-cooling was done by dipping the heads in cold water $\left(0-1^{\circ} \mathrm{C}\right)$ until the 
internal temperature of heads reached $2^{\circ} \mathrm{C}$ which was determined be type-thermocouples inserted into the heads beside non-cooled were used as a control.

After removing the water on the head surface, the artichoke heads from each treatment were packed in polypropylene film $(35 \mathrm{x} 45 \mathrm{~cm})$ of $40 \mu \mathrm{m}$ thickness and each had three artichoke heads represented as one replicate and then heat sealed. Twelve replicates were prepared for each treatment. The samples were arranged in complete randomized design with three replicates and stored at $0^{\circ} \mathrm{C}$ and $95 \% \mathrm{RH}$ for 28 days. Three replicates from each treatment were examined immediately after harvest and every 7 days intervals for the following properties.

Loss in weight percentage calculated by the following equation: Loss in weight $\%=$ Loss in weight at the sampling date / the initial weight of the head X100. The general appearance: as evaluated using a scale from 9 to 1 , where $9=$ excellent, $7=$ good, $5=$ fair, $3=$ poor and $1=$ unsalable heads rating (5) or below were considered as unmarketable, as described by Kader et al. (1973). The compactness: Score rating from 5 to 1 , where $5=$ tight, $4=$ few basal bracts pointing a way from rather than toward tip of bud, $3=$ several whorls of bracts pointing a way from rather than toward tip of bud, $2=$ all or most outer bracts open, $1=$ all outer and more antrally located bracts open. External surface color was evaluated by a color meter (Minolta CR 200) to measure the lightness ( $\mathrm{L}$ value). Ascorbic acid content (as indicated for vit. C). It was determined (as fresh samples of heads) by titration method using 2, 6 discloro phenol indophenols as described in (Ranganna, 1979).

\section{Statistical analysis}

Data were statistically analyzed using the analysis of variance described by Snedecor and Cochran
(1980). The method of Duncan multiple range tests were applied for than comparison between means according to Waller and Duncan (1969).

\section{Results and Discussion}

\section{Weight loss percentage}

Data in Table (1) showed that weight loss percentage of artichoke heads was increased considerably and consistently with the prolongation of storage period. These results were in agreement with those obtained by (Helaly et al., 2016). The loss in weight may be attributed to respiration and other senescence related metabolic processes during storage (Wills et al., 1981).

Concerning the effect of cooling delays on weight loss percentage, data revealed that all cooling delay treatments significantly reduced weight loss \% of artichoke heads as compared with non-cooled during storage. Delaying the precooling for 2 or $4 \mathrm{hr}$. being the most effective treatment for reducing the weight loss $\%$ during storage with significant differences between them. Cooling delay for 6hr. was less effective in this concern. Non cooled treatment gave the highest value of weight loss \%. These results are agreement with Cantwell and Thangaiah (2012) on bell peppers, eggplant and melons; Kitazawa et al. (2013) on strawberry; Saad (2013) on broccoli florets and Gad El-Rab (2018) on snap bean found that loss in weight was negatively affected by delaying the precooling of strawberries fruits, when the precooling was delayed for 6 or $8 \mathrm{hr}$., the fruits showed significantly more shriveling and weight loss $\%$ than in fruits that were promptly cooled. Also, Li et al., (2015) found that the delay from harvest to cool may increase respiration rate and metabolic activity, which in turn increase weight loss \% during storage.

Table 1. Effect of cooling delays on weight loss percentage of artichoke heads during storage in 2017 and 2018 season.

\begin{tabular}{|c|c|c|c|c|c|c|}
\hline \multirow{2}{*}{ Treatments } & \multicolumn{5}{|c|}{ Storage period in days } & \multirow{2}{*}{ means } \\
\hline & Start & 7 & 14 & 21 & 28 & \\
\hline \multicolumn{7}{|c|}{2017 season } \\
\hline After 2 hours & $0.00 \mathrm{I}$ & $0.72 \mathrm{HI}$ & $2.26 \mathrm{FG}$ & $2.98 \mathrm{EF}$ & $3.43 \mathrm{E}$ & $1.88 \mathrm{D}$ \\
\hline After 4 hours & $0.00 \mathrm{I}$ & $1.57 \mathrm{GH}$ & $3.44 \mathrm{E}$ & $3.73 \mathrm{DE}$ & $5.51 \mathrm{C}$ & $2.85 \mathrm{C}$ \\
\hline After 6 hours & $0.00 \mathrm{I}$ & $1.82 \mathrm{G}$ & 3.75 DE & $4.63 \mathrm{CD}$ & $7.37 \mathrm{~B}$ & $3.52 \mathrm{~B}$ \\
\hline Control & $0.00 \mathrm{I}$ & $2.46 \mathrm{FG}$ & $4.86 \mathrm{C}$ & $8.17 \mathrm{~B}$ & $10.19 \mathrm{~A}$ & $5.14 \mathrm{~A}$ \\
\hline means & $0.00 \mathrm{E}$ & $1.64 \mathrm{D}$ & $3.58 \mathrm{C}$ & $4.88 \mathrm{~B}$ & $6.62 \mathrm{~A}$ & \\
\hline \multicolumn{7}{|c|}{2018 season } \\
\hline After 2 hours & $0.00 \mathrm{P}$ & $0.83 \mathrm{O}$ & $2.37 \mathrm{~L}$ & $3.09 \mathrm{~J}$ & $3.54 \mathrm{I}$ & $1.97 \mathrm{D}$ \\
\hline After 4 hours & $0.00 \mathrm{P}$ & $1.68 \mathrm{~N}$ & $3.55 \mathrm{I}$ & $3.84 \mathrm{H}$ & $5.62 \mathrm{D}$ & $2.94 \mathrm{C}$ \\
\hline After 6 hours & $0.00 \mathrm{P}$ & $2.04 \mathrm{M}$ & $3.97 \mathrm{G}$ & $4.85 \mathrm{~F}$ & $7.59 \mathrm{C}$ & $3.69 \mathrm{~B}$ \\
\hline Control & $0.00 \mathrm{P}$ & $2.68 \mathrm{~K}$ & $5.08 \mathrm{E}$ & $8.39 \mathrm{~B}$ & $10.41 \mathrm{~A}$ & $5.31 \mathrm{~A}$ \\
\hline means & $0.00 \mathrm{E}$ & $1.81 \mathrm{D}$ & $3.74 \mathrm{C}$ & $5.04 \mathrm{~B}$ & $6.79 \mathrm{~A}$ & \\
\hline
\end{tabular}

Means in the same column having the same letter are not significantly different at 0.05 levels by Duncan's multiple rang test.

In general, the interaction between cooling delays and storage periods on weight loss $\%$ was significant during all storage periods in the two seasons. After
28 days of storage, data showed that the lowest value of weight loss percentage was observed in delaying 
precooling for 2 or $4 \mathrm{hr}$. with significant differences between them in the two seasons.

\section{General appearance (GA)}

Data in Table (2) revealed that there was significant reduction in GA with the prolongation of storage period. Similar results were reported by (Nobile et al., 2009).

Regarding the effect of cooling delays on GA, data revealed that significant differences in appearance were found among cooling delays on artichoke heads during storage. The GA of heads with delay the precooling for 2, 4 or $6 \mathrm{hr}$. was better than non-cooled. The 2 or $4 \mathrm{hr}$. cooling delay were more effective treatments for maintenance GA with no significant differences between them during storage in the two seasons. These results are in agreement with Makwana et al. (2014) who found that precooling decreases the metabolic activities of harvested produce such as respiration rate and ethylene production ; thus delays the ripening, senescence, decreasing weight loss, retention of firmness, decreasing disease incidence, retain fruit quality during storage and extend the shelf life. Also,Saad (2013) who found that GA of broccoli florets cooled immediately after harvest was good appearance than those cooled after $6 \mathrm{hr}$. delay after 21 days of storage at $0^{\circ} \mathrm{C}$ plus 2 days at $10^{\circ} \mathrm{C}$. Li et al. (2015), on tomatoes, cucumbers and peppers, found that delaying the precooling of product resulted in less attractive and loss of quality characteristics, while those cooled immediately after harvest gave good appearance during storage. Cantwell and Thangaiah (2012) found that decreased general appearance with increased cooling delays was associated with increased dehydration and decay scores and decreases in whole fruit firmness and gloss scores of bell peppers, eggplants and melons.

In general, the interaction between cooling delays and storage period was significant, a 2 or $4 \mathrm{hr}$. delay in hydro-cooling after harvest had the best appearance, which give product with good appearance after 28 days in the two seasons. On the other hand, non-cooled treatment rated poor appearance at the end of storage (28 days).

Table 2. Effect of cooling delays on general appearance (score) of artichoke heads during storage in 2017 and 2018 season.

\begin{tabular}{|c|c|c|c|c|c|c|}
\hline \multirow{2}{*}{ Treatments } & \multicolumn{5}{|c|}{ Storage period in days } & \multirow{2}{*}{ means } \\
\hline & Start & 7 & 14 & 21 & 28 & \\
\hline \multicolumn{7}{|c|}{2017 season } \\
\hline After 2 hours & $9.00 \mathrm{~A}$ & $9.00 \mathrm{~A}$ & $9.00 \mathrm{~A}$ & $8.33 \mathrm{AB}$ & $7.67 \mathrm{BC}$ & $8.60 \mathrm{~A}$ \\
\hline After 4 hours & $9.00 \mathrm{~A}$ & $9.00 \mathrm{~A}$ & $9.00 \mathrm{~A}$ & $7.00 \mathrm{CD}$ & 7.00 CD & $8.20 \mathrm{~A}$ \\
\hline After 6 hours & $9.00 \mathrm{~A}$ & $9.00 \mathrm{~A}$ & $7.67 \mathrm{BC}$ & $6.33 \mathrm{DE}$ & $5.67 \mathrm{EF}$ & 7.53 B \\
\hline Control & $9.00 \mathrm{~A}$ & $9.00 \mathrm{~A}$ & $7.00 \mathrm{CD}$ & $5.00 \mathrm{FG}$ & $3.33 \mathrm{G}$ & $6.67 \mathrm{C}$ \\
\hline means & $9.00 \mathrm{~A}$ & $9.00 \mathrm{~A}$ & 8.17 B & $6.67 \mathrm{C}$ & $5.92 \mathrm{D}$ & \\
\hline \multicolumn{7}{|c|}{2018 season } \\
\hline After 2 hours & $9.00 \mathrm{~A}$ & $9.00 \mathrm{~A}$ & $9.00 \mathrm{~A}$ & $7.67 \mathrm{AB}$ & $7.67 \mathrm{AB}$ & $8.47 \mathrm{~A}$ \\
\hline After 4 hours & $9.00 \mathrm{~A}$ & $9.00 \mathrm{~A}$ & $8.33 \mathrm{AB}$ & $7.00 \mathrm{BC}$ & $7.00 \mathrm{BC}$ & $8.07 \mathrm{~A}$ \\
\hline After 6 hours & $9.00 \mathrm{~A}$ & $9.00 \mathrm{~A}$ & $7.67 \mathrm{AB}$ & $5.67 \mathrm{CD}$ & $3.67 \mathrm{EF}$ & $7.00 \mathrm{~B}$ \\
\hline Control & $9.00 \mathrm{~A}$ & $9.00 \mathrm{~A}$ & $7.00 \mathrm{BC}$ & $5.00 \mathrm{DE}$ & $2.00 \mathrm{D}$ & $6.40 \mathrm{~B}$ \\
\hline means & $9.00 \mathrm{~A}$ & $9.00 \mathrm{~A}$ & 8.00 B & $6.33 \mathrm{C}$ & $5.09 \mathrm{D}$ & \\
\hline
\end{tabular}

\section{Compactness}

Data in Table (3) showed that compactness (score) of artichoke heads was decreased with the prolongation of storage period. These results were in agreement with (Atala, 2006). Concerning the effect of cooling delays on compactness of artichoke heads, data revealed that all cooling delay treatments significantly maintained head compactness as compared with non-cooled treatment during storage in the two seasons. The highest values of heads compactness score were obtained by all cooling delay treatments $(2,4$ and $6 \mathrm{hr}$.) with no significant differences between them in the two seasons. On the other hand, the lowest values were recorded in noncooled heads (control).

As for the interaction between cooling delay treatments and storage period, data showed that precooling delays for 2,4 or $6 \mathrm{hr}$. had higher compactness score with nosignificant differences between them compared with non-cooled treatment after 28 days of storage. 
Table 3. Effect of cooling delays on compactness (score) of artichoke heads during storage in 2017 and 2018 season.

\begin{tabular}{|c|c|c|c|c|c|c|}
\hline \multirow{2}{*}{ Treatments } & \multicolumn{5}{|c|}{ Storage period in days } & \multirow{2}{*}{ means } \\
\hline & Start & 7 & 14 & 21 & 28 & \\
\hline \multicolumn{7}{|c|}{2017 season } \\
\hline After 2 hours & $5.00 \mathrm{~A}$ & $5.00 \mathrm{~A}$ & $5.00 \mathrm{~A}$ & $5.00 \mathrm{~A}$ & $4.00 \mathrm{~B}$ & $4.80 \mathrm{~A}$ \\
\hline After 4 hours & $5.00 \mathrm{~A}$ & $5.00 \mathrm{~A}$ & $5.00 \mathrm{~A}$ & $5.00 \mathrm{~A}$ & $4.00 \mathrm{~B}$ & $4.80 \mathrm{~A}$ \\
\hline After 6 hours & $5.00 \mathrm{~A}$ & $5.00 \mathrm{~A}$ & $5.00 \mathrm{~A}$ & $5.00 \mathrm{~A}$ & $4.00 \mathrm{~B}$ & $4.80 \mathrm{~A}$ \\
\hline Control & $5.00 \mathrm{~A}$ & $5.00 \mathrm{~A}$ & $4.00 \mathrm{~B}$ & $3.33 \mathrm{C}$ & $3.00 \mathrm{D}$ & $4.07 \mathrm{~B}$ \\
\hline means & $5.00 \mathrm{~A}$ & $5.00 \mathrm{~A}$ & $4.75 \mathrm{~B}$ & $4.58 \mathrm{C}$ & $3.75 \mathrm{D}$ & \\
\hline \multicolumn{7}{|c|}{2018 season } \\
\hline After 2 hours & $5.00 \mathrm{~A}$ & $5.00 \mathrm{~A}$ & $5.00 \mathrm{~A}$ & $4.67 \mathrm{AB}$ & $3.67 \mathrm{BC}$ & $4.67 \mathrm{~A}$ \\
\hline After 4 hours & $5.00 \mathrm{~A}$ & $5.00 \mathrm{~A}$ & $5.00 \mathrm{~A}$ & $4.67 \mathrm{AB}$ & $3.67 \mathrm{BC}$ & $4.67 \mathrm{~A}$ \\
\hline After 6 hours & $5.00 \mathrm{~A}$ & $5.00 \mathrm{~A}$ & $4.67 \mathrm{AB}$ & $4.67 \mathrm{AB}$ & $3.33 \mathrm{C}$ & $4.53 \mathrm{~A}$ \\
\hline Control & $5.00 \mathrm{~A}$ & $5.00 \mathrm{~A}$ & $3.67 \mathrm{BC}$ & $3.00 \mathrm{C}$ & $2.00 \mathrm{D}$ & $3.70 \mathrm{~B}$ \\
\hline means & $5.00 \mathrm{~A}$ & $5.00 \mathrm{~A}$ & $4.58 \mathrm{AB}$ & $4.25 \mathrm{~B}$ & $3.17 \mathrm{C}$ & \\
\hline
\end{tabular}

Means in the same column having the same letter are not significantly different at 0.05 levels by Duncan's multiple rang test.

\section{Color}

Changes in lightness ( $\mathrm{L}$ value) were observed during storage compared to initial value. Lightness of artichoke heads was affected by storage time. A decrement in $\mathrm{L}$ value was detected by prolonging the storage period (Table 4), resulted darker color. Concerning cooling delay treatments, data show that there were significant differences among cooling delay treatments. All cooling delays gave the highest value of $\mathrm{L}$ value as compared with non-cooled. Delaying precooling for 2 or $4 \mathrm{hr}$. being the most effective treatment in maintaining the $\mathrm{L}$ values, resulted in lighter color with no significant differences between them in the first season, while non-cooled treatment give the lowest value of $\mathrm{L}$ value during storage, resulted in darker color. These results were achieved in the two seasons and are in agreement with Yettella et al. (2010) who found that long postharvest cooling delay and duration negatively affected broccoli color. Also, Saad (2013) found that cooling delay for $6 \mathrm{hr}$. resulted in broccoli sprout with significantly lower $\mathrm{L}$ value than promptly precooled product. These color changes may be a consequence of the greater moisture loss and over ripeness of the fruit from the delayed treatment (Nunes et al., 1995).

Table 4. Effect of cooling delays on color (L value) of artichoke heads during storage in 2017 and 2018 season.

\begin{tabular}{|c|c|c|c|c|c|c|}
\hline \multirow{2}{*}{ Treatments } & \multicolumn{5}{|c|}{ Storage period in days } & \multirow{2}{*}{ means } \\
\hline & Start & 7 & 14 & 21 & 28 & \\
\hline \multicolumn{7}{|c|}{2017 season } \\
\hline After 2 hours & $50.61 \mathrm{~A}$ & $45.15 \mathrm{~B}$ & $41.07 \mathrm{CD}$ & $39.34 \mathrm{DE}$ & $35.30 \mathrm{FG}$ & $42.29 \mathrm{~A}$ \\
\hline After 4 hours & $50.61 \mathrm{~A}$ & $44.00 \mathrm{BC}$ & $41.25 \mathrm{CD}$ & $37.11 \mathrm{EF}$ & $33.40 \mathrm{GH}$ & 41.28 AB \\
\hline After 6 hours & $50.61 \mathrm{~A}$ & $43.67 \mathrm{BC}$ & 39.61 DE & $35.20 \mathrm{FG}$ & $31.60 \mathrm{H}$ & 40.14 B \\
\hline Control & $50.61 \mathrm{~A}$ & $41.84 \mathrm{BD}$ & $39.05 \mathrm{DE}$ & $32.20 \mathrm{GH}$ & $25.20 \mathrm{I}$ & $37.78 \mathrm{C}$ \\
\hline means & $50.61 \mathrm{~A}$ & 43.67 B & $40.25 \mathrm{C}$ & $35.96 \mathrm{D}$ & $31.38 \mathrm{E}$ & \\
\hline \multicolumn{7}{|c|}{2018 season } \\
\hline After 2 hours & $50.21 \mathrm{~A}$ & $43.95 \mathrm{~B}$ & $39.87 \mathrm{EF}$ & $38.14 \mathrm{G}$ & $34.10 \mathrm{~K}$ & $41.25 \mathrm{~A}$ \\
\hline After 4 hours & $50.21 \mathrm{~A}$ & $42.80 \mathrm{C}$ & $40.05 \mathrm{E}$ & $35.91 \mathrm{~J}$ & $32.20 \mathrm{M}$ & $40.23 \mathrm{~B}$ \\
\hline After 6 hours & $50.21 \mathrm{~A}$ & $41.57 \mathrm{D}$ & $37.51 \mathrm{H}$ & $33.10 \mathrm{~L}$ & $29.50 \mathrm{O}$ & $38.38 \mathrm{C}$ \\
\hline Control & $50.21 \mathrm{~A}$ & $39.44 \mathrm{~F}$ & $36.95 \mathrm{I}$ & $30.10 \mathrm{~N}$ & $23.10 \mathrm{P}$ & $35.96 \mathrm{D}$ \\
\hline means & $50.21 \mathrm{~A}$ & 41.94 B & $38.60 \mathrm{C}$ & 34.31 D & $29.73 \mathrm{E}$ & \\
\hline
\end{tabular}

Means in the same column having the same letter are not significantly different at 0.05 levels by Duncan's multiple rang test.

Changes in hue angle values of artichoke heads are good indicator of senescence. As shown in Table (5) showed that the hue angle values of artichoke heads gradually decreased as the storage period extended indicating that artichoke heads turned to slight yellow as the storage period prolonged. These results were true in the two seasons and were an agreement with (Atala, 2006).
Concerning the effect of cooling delay treatments on hue angle values, data showed that all cooling delays gave the highest value of $h^{\circ}$ value as compared with non-cooled. Delaying precooling of artichoke heads for 2 or $4 \mathrm{hr}$. were more green color of heads (higher value of hue angle) as compared to cooling delay for $6 \mathrm{hr}$. during storage in the two seasons. On the other hand, non-cooled treatment gave the lower value of hue angle as an important degreening or intense yellowing. 
Table 5. Effect of cooling delays on color (hue angle $h^{\circ}$ ) of artichoke heads during storage in 2017 and 2018 season.

\begin{tabular}{|c|c|c|c|c|c|c|}
\hline \multirow{2}{*}{ Treatments } & \multicolumn{5}{|c|}{ Storage period in days } & \multirow{2}{*}{ means } \\
\hline & Start & 7 & 14 & 21 & 28 & \\
\hline \multicolumn{7}{|c|}{2017 season } \\
\hline After 2 hours & $86.31 \mathrm{~A}$ & $85.21 \mathrm{~B}$ & $84.31 \mathrm{D}$ & $82.51 \mathrm{~F}$ & $81.67 \mathrm{H}$ & $84.00 \mathrm{~A}$ \\
\hline After 4 hours & $86.31 \mathrm{~A}$ & $85.00 \mathrm{C}$ & $83.00 \mathrm{E}$ & $80.24 \mathrm{I}$ & $79.22 \mathrm{~J}$ & 82.75 B \\
\hline After 6 hours & $86.31 \mathrm{~A}$ & $82.11 \mathrm{G}$ & $80.24 \mathrm{I}$ & $77.21 \mathrm{~L}$ & $74.11 \mathrm{M}$ & $80.00 \mathrm{C}$ \\
\hline Control & $86.31 \mathrm{~A}$ & $80.23 \mathrm{I}$ & $78.11 \mathrm{~K}$ & $73.31 \mathrm{~N}$ & $70.23 \mathrm{O}$ & $77.64 \mathrm{D}$ \\
\hline means & $86.31 \mathrm{~A}$ & 83.14 B & 81.42 C & 78.32 D & $76.31 \mathrm{E}$ & \\
\hline \multicolumn{7}{|c|}{2018 season } \\
\hline After 2 hours & $92.32 \mathrm{~A}$ & $91.30 \mathrm{~B}$ & $90.40 \mathrm{C}$ & $89.11 \mathrm{E}$ & $87.20 \mathrm{G}$ & $90.07 \mathrm{~A}$ \\
\hline After 4 hours & $92.32 \mathrm{~A}$ & $90.00 \mathrm{D}$ & $88.20 \mathrm{~F}$ & $86.24 \mathrm{I}$ & $86.40 \mathrm{H}$ & 88.63 B \\
\hline After 6 hours & $92.32 \mathrm{~A}$ & $87.21 \mathrm{G}$ & $85.21 \mathrm{~K}$ & $82.00 \mathrm{~L}$ & $80.00 \mathrm{~N}$ & 85.35 C \\
\hline Control & $92.32 \mathrm{~A}$ & $86.00 \mathrm{~J}$ & $81.11 \mathrm{M}$ & $78.23 \mathrm{O}$ & $75.32 \mathrm{P}$ & 82.60 D \\
\hline means & $92.32 \mathrm{~A}$ & 88.63 B & 86.23 C & 83.89 D & $82.23 \mathrm{E}$ & \\
\hline
\end{tabular}

Means in the same column having the same letter are not significantly different at 0.05 levels by Duncan's multiple rang test.

\section{Ascorbic acid content}

Data in Table (6) showed that ascorbic acid content of artichoke heads was significantly decreased with the prolongation of storage period. Similar results were obtained by (Atala, 2006).

As cooling delay treatments, data found that there were significant differences between cooling delay treatments and non-cooled of heads. However, cooling delay for $2 \mathrm{hr}$. after harvest was effective on preventing ascorbic acid degradation during storage as compared with precooling delay for 4 or $6 \mathrm{hr}$. with significant differences between them. The lowest values of ascorbic acid content resulted from noncooled treatment. These results were in agreement with Nunes et al. (1995) and Kitazawa et al. (2013) on strawberries.

For the interaction between cooling delay treatments and storage period after 28 days of storage, data revealed that delaying precooling for $2 \mathrm{hr}$. was being the most effective treatments in maintaining ascorbic acid content as compared to the other cooling delays or non-cooled.

Table 6. Effect of cooling delays on ascorbic acid content ( $\mathrm{mg} / 100 \mathrm{gm}$ f.w.) of artichoke heads during storage in 2017 and 2018 season.

\begin{tabular}{lcccccc}
\hline \multirow{2}{*}{ Treatments } & \multicolumn{7}{c}{ Storage period in days } & \multirow{2}{*}{ means } \\
\cline { 2 - 6 } & Start & $\mathbf{7}$ & $\mathbf{1 4}$ & $\mathbf{2 1}$ & $\mathbf{2 8}$ & \\
\hline After 2 hours & $85.80 \mathrm{~A}$ & $84.00 \mathrm{~A}$ & $82.13 \mathrm{AB}$ & $76.67 \mathrm{AD}$ & $77.87 \mathrm{AC}$ & $\mathbf{8 1 . 2 9} \mathbf{A}$ \\
After 4 hours & $85.80 \mathrm{~A}$ & $81.20 \mathrm{AB}$ & $75.07 \mathrm{AE}$ & $68.33 \mathrm{BF}$ & $60.13 \mathrm{EG}$ & $\mathbf{7 4 . 1 1} \mathbf{B}$ \\
After 6 hours & $85.80 \mathrm{~A}$ & $81.20 \mathrm{AB}$ & $74.67 \mathrm{AE}$ & $61.67 \mathrm{DF}$ & $54.27 \mathrm{FG}$ & $\mathbf{7 1 . 5 2} \mathbf{B}$ \\
Control & $85.80 \mathrm{~A}$ & $72.80 \mathrm{AE}$ & $63.47 \mathrm{CF}$ & $53.33 \mathrm{FG}$ & $40.47 \mathrm{H}$ & $\mathbf{6 3 . 1 7} \mathbf{C}$ \\
means & $\mathbf{8 5 . 8 0 \mathrm { A }}$ & $\mathbf{7 9 . 8 0 A B}$ & $\mathbf{7 3 . 8 3} \mathbf{B}$ & $\mathbf{6 5 . 0 0} \mathbf{C}$ & $\mathbf{5 8 . 6 8} \mathbf{D}$ & \\
\hline & & & $\mathbf{2 0 1 8}$ season & & & \\
\hline After 2 hours & $83.20 \mathrm{~A}$ & $81.60 \mathrm{AB}$ & $79.73 \mathrm{AC}$ & $74.27 \mathrm{CE}$ & $75.47 \mathrm{BE}$ & $\mathbf{7 8 . 8 5} \mathbf{A}$ \\
After 4 hours & $83.20 \mathrm{~A}$ & $78.80 \mathrm{AD}$ & $72.67 \mathrm{DE}$ & $55.93 \mathrm{FG}$ & $57.73 \mathrm{~F}$ & $\mathbf{6 9 . 6 7} \mathbf{B}$ \\
After 6 hours & $83.20 \mathrm{~A}$ & $78.20 \mathrm{AD}$ & $71.67 \mathrm{E}$ & $58.67 \mathrm{~F}$ & $51.27 \mathrm{G}$ & $\mathbf{6 8 . 6 0} \mathbf{B}$ \\
Control & $83.20 \mathrm{~A}$ & $69.80 \mathrm{E}$ & $60.47 \mathrm{~F}$ & $50.33 \mathrm{G}$ & $37.47 \mathrm{H}$ & $\mathbf{6 0 . 2 5} \mathbf{C}$ \\
means & $\mathbf{8 3 . 2 0 ~ A}$ & $\mathbf{7 7 . 1 0} \mathbf{B}$ & $\mathbf{7 1 . 1 4} \mathbf{C}$ & $\mathbf{5 9 . 8 0} \mathrm{D}$ & $\mathbf{5 5 . 4 9} \mathbf{E}$ & \\
\hline
\end{tabular}

Means in the same column having the same letter are not significantly different at 0.05 levels by Duncan's multiple rang test.

\section{References}

Atala, S.A. 2006. Effect of some treatments for improving the quality and increasing storage ability of globe artichoke. M.Sc. Thesis, Fac., Agric., Cairo Univ.,Egypt.

Azzini, E.; I. Pugianesi; F. Ronano; D. Venere; D. Miccadei and S. Durazzo, 2007. Absorption and metabolism of bioactive molecules after oral consumption of cooked edible heads of Cynara scolymus L. (Cultivar violettodiprovenza) in human subjects: a pilot study. Briti. J. nutr., 197(5): 963-969.

Becker, B.R. and B.A. Fricke, 2002. Hydro-cooling time estimation methods. Intl. Commun. Heat Mass Transfer, 29: 165-174.

Brecht, J. 2008. WFLO Commodity Storage Manual. Review article, institute of food and agriculture sciences, Univ. Florida. 
Cantwell, M.I. and A. Thangaiah, 2012. Acceptable cooling delays for selected warm season vegetables and melons. Acta Hort., 934: 77-84.

Gad El-Rab, N.A. 2018.Effect of some pre and postharvest treatments on yield, quality and storability of snap beans. Ph.D. Thesis, Fac. Agric., Cairo Univ., Cairo, Egypt, 252 p.

Helaly, A.A., I.A.A. Haggag; S.A. Shanan; A.S.A. Abbo El-Hamd and R.E.I. El-Bassiouny, 2016. Effect of chemical treatments on the quality of fresh-cut globe artichoke (Cynara scolymus, L.) during cold storage. Adv. Plants Agric., Res., 5(2):1-11.

Kader, A.A.; L.L. Morris and E.C. Maxie, 1973. Systems for scoring quality of harvested lettuce. Hort. Sci., 8:408-409.

Kader, A.A. 1992. Postharvest biology and technology: an overview. In A.A. Kader (ed.). Postharvest technology of horticultural crops. California: UniV. Califo. Pupli., P.15-20.

Kitazawa, H., T. Sato, N. Nakamura and S. Motoki, 2013. Effect of post-harvest cooling delay on weight loss, soluble solid and ascorbic acid contents of strawberry fruit. J. Food Agric. Environ., 11 (3\&4): 372 - 376.

Lavermicocca, P.; M. Dekker; M. Russo; F. Valerio; F. Di Venere and D. Sisto, 2016. Lactobacillus paracasei-enriched vegetables containing health promoting molecules. In-R.R.Watson \& V.R. preedy (Eds.). Probiotics, prebiotics and synbiotics. Pioactive foods in health promotion (pp 361-370). San Diego, CA, USA: Elsevier Academic press.

Li, L.; A. Lichter; D. kenigsbuch and R. Porat, 2015. Effect of cooling delays at the wholesale market on the quality of fruit and vegetables after retail marketing. J. Food Proce. Preserv., 39: 25332547.

Makwana, S.A.; N.D. Polara and R.R. Viradia, 2014. Effect of pre-cooling on postharvest life of mango (Mangiferaindica L.) CV. Kesar. Food Sci. and Techn., 2(1):6-13.

Mileo, A.M., D. Di Venere; V. Linsalata, R. Fraioli and S. Miccadei, 2012. Artichoke polyphenoles induce apoptosis and decrease the invasive potential the human breast cancer line MDAMB231. J. cellular physio., 227:3301-3309.
Nobile, M.A.; A. Conte; C. Scrocco; J. Laverse; I. Brescia; G. Conversa and A. Elia, 2009. New packaging strategies to preserve fresh-cut artichoke quality during refrigerated storage. Innovative Food Science and Emerging Techn., 10: $128-133$.

Nunes, M.C.N.; J.K. Brecht; A.M.M.B. Morais and S.A. Sargent. 1995. Physical and chemical quality characteristics of strawberries after storage are reduced by a short delay to cooling. Postharvest Biol. Technol., 6: 17-28.

Ranganna, S. 1979. Manual of analysis of fruit and vegetable products. Central Food Technological Research Institute. Oh.D. Published 12/4Asaf Ali ROAD,New Delhi 110002, and printed at raj Bandhu Industrial Company, C-16, May a puri, phase 11, New Delhi, 1100064.

Saad, M.El-M. 2013. Effect of modified atmosphere storage on postharvest quality of some nontraditional vegetable crops. Ph.D. Thesis. Fac., Agric., Ain Shams Univ., Cairo, Egypt. stage. J. Food Safet., 9: 37-44.

Salazar, N.; A.M. Dewulf; A.M. Neyrinck; L.B. Bindels; P.D. Cani and L. Mahillon, 2015. Inulintype fructans modulate intestinal Bifidobacterium species populations and decrease fecal shortchain fatty acids in obese women. Clinical Nutrition, 34:501-507.

Shehata, S. and M. Tariq, 2007. Effect of different field heat removable systems on quality of tomato during ripening stage. J. Food Safet., 9: 37-44.

Snedecor, G.W. and W.G. Cochran, 1980.Statistical methods. $6^{\text {th }}$ Iowa State Univ. Press, USA.

Waller, R.A. and D.B. Duncan, 1969. A buyes rule for the symmetric multiple comparison problems. Amer. State. Assoc. J., 64:1484-1503.

Wills, R.H.H.; T.H. Lee, D. Gerham; W.B. McGlasson and E.G. Hall, 1981. Postharvest and introduction to physiology and handling of fruits and vegetables. The AVF publishing Comp. Inc. estport. Conn., pp. 35.

Yettella, V.; R. Reddy; J. Marcy; A.D. Bratsch; R.C. Williams and K.M. Waterman, 2010. Effect of packaging and postharvest treatment on the shelflife quality of crown-cut broccoli. J. Food Quali., 33(5): 599-611.

\section{تأثير تأخير التبريد المبدئى على صفات الجودة لنورات الخرشوف خلال التخزين المبرد.}




\section{صلاح الدين أحمد محمدين, محسن السيد محمد سعد, شيرين عطا عطا الله, إبتسام حميده عيسى عفيفى معهذ بحوث البساتين -مركز البحوث الزراعية بالجيزة.}

تم جمع نورات الخرشوف صنف French Hyrious فى مرحلة القطف المناسبة للنسويق (قطر 7-12 سم) فى 14، 16 فبراير سنة 2017 ، 2018 على التوالى من مزرعة برج العرب محافظة البحيرة ثم نقلت الى معمل بحوث تداول الخضر - معهد بحوث البساتين - مركز البحوث الزراعية لدراسة تأثير التأخير فى إجراء التبريد المبدئى بعد (2, 4 ، 6 ساعات) من الحصاد بالمقارنة مع النورات غير المبردة (المقارنة)

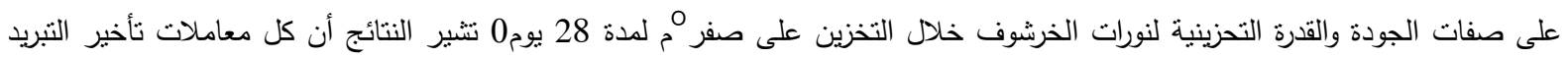
أدت إلى تقليل نسبة فقد الوزن كما حافظت على أندماج النورات وكمية فيتامين ج ونسبة المواد الصلبة الذائبة مقارنة بالنورات غير المبردة خلاد

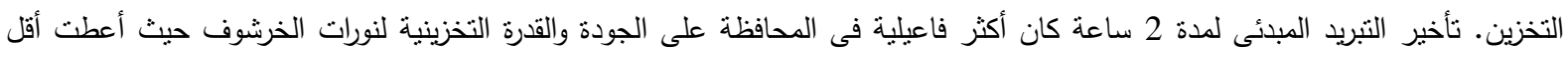

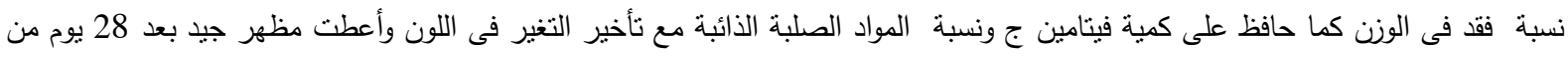

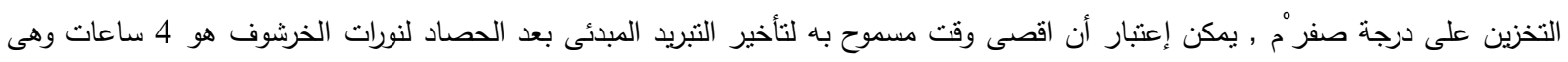
الفترة التى لم تؤثر على صفات جودة النورات وأعطت مظهر جيد بعد 28 يوم من التخزين على درجة صفر مُ مُ أعطت المعاملة غير المبردة

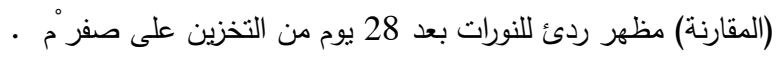

